\title{
VIAJAR ES PRECISO
}

Maria Baranda*

\section{El que viaja no le teme a las tinieblas.}

Se adentra, hace un reconocimiento del sitio y se vuelve una autoridad natural para hablar del lugar. Hay un ímpetu en el viajero: hacer lo necesario para compensar el impulso que da el trazar un rastro que lo hace presente y único. El que viaja huye de la sospecha: no se detiene, actúa sin ninguna inhibición para hacer del recorrido algo necesario, algo vital, algo que le otorgue el esplendor de ver y vivir el sitio. El que viaja tiene la confianza, algunas veces, de ir a la deriva, de saberse parte de un sueño que zozobra. El vacío no existe para él, porque sabe que justo ahí se separa del resto de los hombres, de los que pasan y dicen "aquí vivo" o "soy de aquí" y buscan, buscan un puerto. Viajar es encontrar un cumplimiento, una manera de estar y de exigirse en la extrañeza. Pero la extrañeza no existe, al menos no para él, porque el viajero es quien elimina el afuera y se lo apropia hasta convertirlo en algo entrañable. Viajar, entonces, es ser víctima de sí mismo frente al protagonismo de una civilización o, cuando menos, si se puede decir esto, de una cultura. La entraña es lo que cuenta. La entraña es estar hartos de los márgenes y del silencio infinito de las geografías, del despliegue del viento en una ciudad cualquiera que acompasa, siempre acompasa, el movimiento de la imaginación en la imaginación del alma. El que viaja recorre un siglo y otro y otro más, todos los necesarios, para quedar-

* Poeta. 
se sometido al momento. En su conciencia crece sólo el límite de su idealismo: juega a ver con plenitud aquello que hubo y que reta y provoca la conciencia contemporánea devorada por su propia existencia. Juega, sí, el viajero juega el juego de la vida y, a veces, como en el caso de Julián Meza, declara que el sueño es la realidad, pero la realidad es profana, nos dice el autor.

Julián provoca, siempre provoca, como si fuera el último que pudiera nombrar un sitio en sus huellas, un estigma de lo que vio, y decir a corazón abierto: Constantinopla. Así, despacio, arrimándola a nuestras vidas, prolongando su desesperanza anegada en una luz todavía distante. Todavía. Todavía porque tenemos que leer en la escritura de Julián su condición de sitio, de lo que significa toda ella en la idea de lo que fue y que ahora es. Julián Meza parece decirnos que hay un sentido no revelado en el lugar, un sentido que se hunde, como el fondo de un secreto, más allá de una muralla que ya no está, de un mar apaciguado con su tinta relumbrante y su abandono ante nosotros. "Soy, soy en la bruma y estoy para ti”, nos dice Hagia Sophia, y soy más allá de "toda imagen y semejanza", porque "mío fue el Reino". Hermana de lo invisible, el sitio estuvo para el viajero Julián que se fue remando, siglos atrás, y que hundió su palabra en sus aguas como en la sombra de sí mismo. Y vio y se consumió lentamente en un grito. Porque Constantinopla es un grito bajo las cisternas y los pozos que recorren por debajo a la ciudad. Y es también un grito en el árbol de toda la sapiencia. Sin embargo, antes de llegar a ella (si es que algún día se llega), habrá que bordear otros abismos y hacer un previo peregrinaje por laberínticos conos de piedra para ir a Capadocia y ver los frescos bizantinos desdibujados por los enemigos de Bizancio y por la ignorancia de muchos otros depredadores. Y de allí a Kayseri, a Göreme, pasando por Ürgüp y por Éfeso con los restos de una biblioteca que sufrió el incendio de los bárbaros, toda una geografía que sostiene el aliento de un presente convertido en pasado.

Porque en el libro se habla de un espacio de vida en donde se establece el vaivén hacia la muerte y de ahí, de nuevo, hacia la vida. Y porque todo se apura en esta época hasta agotar la existencia. Y porque, como 
se subraya en el texto: "Nadie va a Istanbul a buscar los vestigios de Constantinopla". Nadie excepto quien se atreve a imaginar lo inescrutable o quien, como en el poema "Los ángeles son blancos" de Seferis, sepa que no hay otro camino porque:

es preciso volverse como la piedra cuando uno busca la compañía de la piedra, y cuando uno busca el milagro es preciso sembrar su sangre a los ocho rincones del viento,

por cuanto el milagro no está en ninguna parte, sino que circula por las venas del hombre.

Julián Meza escribe una bitácora personal en donde el mundo es un relato que corre por la fabulación de su imaginario, con la fuerza de quien ve lo posible dondequiera que puede, de quien establece una aventura en la piedad de su espíritu y de quien recolecta un relato tras otro más allá de la historia y del conocimiento de los hechos. Así, cualquier circunstancia, le sirve al autor para encontrarse más allá de sí mismo y más allá del ir y venir de una ciudad de inspiración luminosa.

Un libro como éste funciona como una gran memoria que incorpora las lúcidas anotaciones del viajero con la idea de un espacio vuelto código cultural del antes y el ahora, donde se congregan, felizmente para nosotros, asombrados lectores, la evocación de un mundo y la vitalidad de una pluma. Y si en las entrañas del olvido logramos recuperar la conquista de un sitio en la mudez de un grito, estaremos seguros, como nos ha enseñado Julián Meza con su isla del mediodía, de que viajar es preciso, porque nos ha mostrado que el milagro circula por las venas de este libro. 
CITAM Derechos Reservados.

La reproducción total o parcial de este artículo se podrá hacer si el ITAM otorga la autorización previamente por escrito.

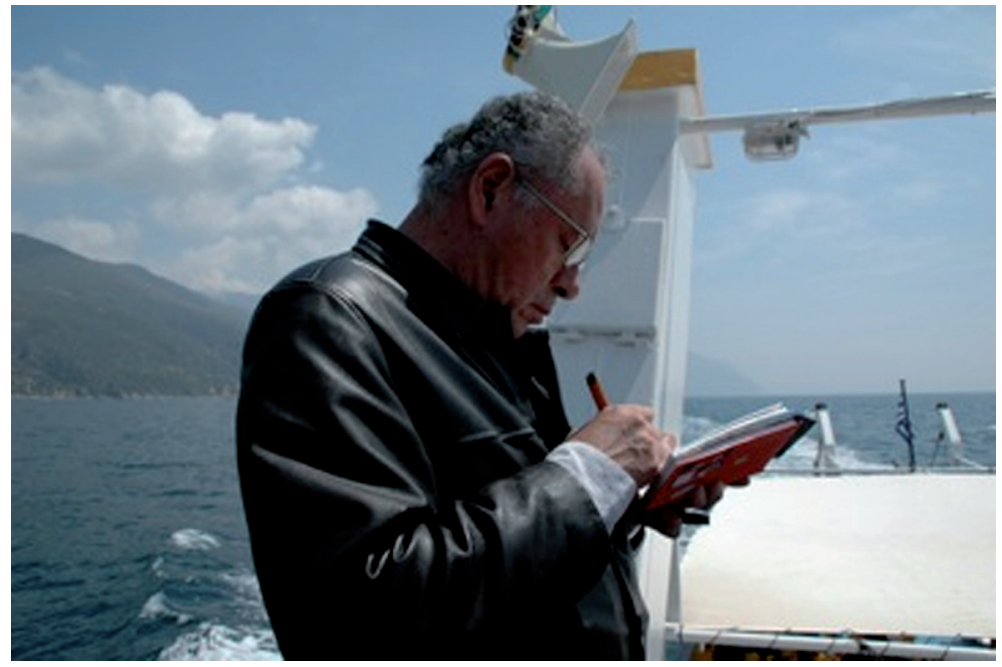

Frente a la costa del monte Athos, en Grecia, 2006. 